\title{
Amblyopia after unilateral infantile cataract extraction after six weeks of age
}

\author{
Ambliopia no pós-operatório de catarata congênita unilateral \\ operada após seis semanas de vida
}

\author{
Fábio Ejzenbaum ${ }^{1}$ \\ Solange Rios Salomão ${ }^{2}$ \\ Adriana Berezovsky ${ }^{3}$ \\ Mauro Waiswol ${ }^{4}$ \\ Márcia Beatriz Tartarella ${ }^{5}$ \\ Paula Yuri Sacai ${ }^{6}$ \\ Josenilson Martins Pereira ${ }^{7}$
}

\begin{tabular}{|l|}
\hline \multicolumn{1}{c|}{ ABSTRACT } \\
\hline Purpose: To determine interocular grating acuity difference in children \\
treated for unilateral infantile cataract. Methods: A group of 27 children \\
previously treated for unilateral infantile cataract, had their monocular \\
visual acuity measured by sweep visual evoked potentials. Interocular \\
grating acuity difference was calculated as the absolute subtraction of \\
monocular acuity scores. Lens status, opacity severity and eye alignment \\
were considered for analysis. Results: Mean interocular grating acuity \\
difference obtained from unilateral cataract patients was $0.58 \pm 0.20$ \\
logMAR. This result was significantly larger than 0.10 logMAR used as \\
normative data. Children with severe opacities had a more pronounced \\
amblyopia than the moderate ones. No significant correlation between \\
amblyopia and strabismus or aphakia was found. Conclusions: Interocular \\
acuity difference in this group of unilateral congenital cataract was more \\
pronounced than previous reports, mainly because of delay in diagnosis, \\
surgery and optical correction.
\end{tabular}

Keywords: Amblyopia/etiology; Cataract/congenital; Cataract/complications; Postoperative complications Brazil; Médico colaborador do Setor de Eletrofisiologia Visual Clínica da Universidade Federal de São Paulo UNIFESP - São Paulo (SP) - Brazil.

2. $\mathrm{PhD}$, Professora Associada da UNIFESP, Chefe do Setor de Eletrofisiologia Visual Clínica daUNIFESP - São Paulo (SP) - Brazil

PhD, Professora Associada da UNIFESP - São Paulo (SP) - Brazil.

4. $\mathrm{PhD}$, Chefe do Setor de Catarata Congênita do Departamento de Oftalmologia da Santa Casa de São Paulo São Paulo (SP) - Brazil.

5. $\mathrm{PhD}$, Chefe do Setor de Catarata Congênita do Departamento de Oftalmologia da UNIFESP - São Paulo (SP) Brazil.

6. Tecnóloga do Departamento de Oftalmologia da UNIFESP - São Paulo (SP) - Brazil.

7. Tecnólogo do Departamento de Oftalmologia da UNIFESP - São Paulo (SP) - Brazil.

Address for correspondence: Fábio Ejzenbaum. Rua Dr. Albuquerque Lins, 1.144 - Apto. 82 - São Paulo (SP) CEP 01230-001

E-mail: fabio_e@terra.com.br

Recebido para publicação em 07.11.2008

Última versão recebida em 09.07.2009

Aprovação em 14.07.2009

Nota Editorial: Depois de concluída a análise do artigo sob sigilo editorial e com a anuência do Dra. Rosane da Cruz Ferreira sobre a divulgação de seu nome como revisora, agradecemos sua participação neste processo.

\section{INTRODUCTION}

Infantile cataract interferes in the development of the visual system; being an important challenge for pediatric ophthalmology. The clinical approach, surgical treatment, optical rehabilitation and prognosis, are very peculiar, and quite different from adult cataracts ${ }^{(1-2)}$. Among children with ophthalmologic diseases, congenital cataract has an incidence of $4 \%^{(3-4)}$, and a prevalence of $6 \%$ among newborns with anterior segment problems ${ }^{(5)}$.

Unilateral cataracts have a worse prognosis than bilateral ones. Visual acuity is usually worse in the affected eye, because of the lack of an appropriate stimulation, poor accommodative stimulus and a lower eye growth ${ }^{(6)}$.

Age limits to achieve satisfactory visual acuity are also smaller in unilateral congenital cataracts. There is some controversy in the literature regarding the optimal age for surgical removal. Surgery up to 6 weeks of life is believed to provide good outcomes ${ }^{(7-9)}$, with a maximum limit until 12 weeks of age ${ }^{(10)}$. On the other hand, visual acuity of $20 / 60$ could be achieved in uncomplicated cases with surgery in the first 6 months of age ${ }^{(6)}$.

Amblyopia could be defined as the interruption of visual acuity development caused by lack of stimuli or inappropriate or insufficient stimuli during critical periods of development. It can be classified as strabismic, anisometropic, ammetropic or deprivational. The last one includes congenital cataracts. The treatment of infantile cataract is based on two major approa-
\end{abstract}


ches: surgical removal of the opacified lens and optical rehabilitation. This rehabilitation can be achieved with intraocular lens (IOL) implantation plus optical correction or optical correction without IOL implant. In Brazilian public hospitals most of infantile cataract patients are left aphakic with glasses as the first choice for optical correction. Consequently, aniseikonia is quite common in these patients. Pseudophakia followed by glasses for near distance are still not the first available therapeutic option.

Grating acuity can be measured through psychophysical and electrophysiological methods in infants and pre-verbal children. An efficient electrophysiological method is the Sweep Visual Evoked Potential (SVEP) described by Tyler et al ${ }^{(11)}$. With this technique, a range of spatial frequencies can be swept in a 10 second presentation interval providing a fast and reliable grating acuity threshold. An additional advantage is the agreement between grating acuity measured by sweep-VEP and optotype acuity ${ }^{(12)}$.

The purpose of this study was to determine the severity of amblyopia provided by the calculation of interocular grating acuity difference obtained by SVEP testing in children surgically trated for unilateral congenital cataract.

\section{METHODS}

\section{Participants}

A group of 27 children previously diagnosed and operated for unilateral infantile cataract underwent monocular grating acuity measurement by sweep-VEP in the Clinical Electrophysiology of Vision Laboratory of the Department of Ophthalmology, Federal University of São Paulo (UNIFESP), São Paulo, Brazil. Testing sessions took place between October 2002 and June 2004. Patients were recruited from the Congenital Cataract Clinic of the Department of Ophthalmology, Federal University of São Paulo $(n=21)$ and Santa Casa School of Medicine $(\mathrm{n}=06)$. Inclusion criteria were absence of surgical complications, absence of any neurological diseases and congenital cataract as the sole ophthalmic disease. Informed consent was obtained from parents before testing and the tenets of the Declaration of Helsinki were followed. This study protocol was approved by the Institutional Review Board (Committee of Ethics in Research) of Federal University of São Paulo (nำ 216/02).

Aphakic eyes were previously submitted to lensectomy and pseudophakic ones to phacoemulsification. Among these 27 cases, 20 were wearing spectacle correction and 7 had intraocular lens implantation (IOL) plus spectacle correction. Refractive status was reviewed monthly and glasses were prescribed, if necessary, as optical correction. Preoperatively, 8 eyes were classified as having moderate lens opacities, and 19 as dense opacities.

Patching therapy for amblyopia was prescribed after optical correction as this scheme: children between 2-4 months of age (patching the fellow eye 2-4 hours/day), children between 4-
6 months of age (patching the fellow eye 4-6 hours/day), children older than 6 months (patching 50\% of the day). Overall compliance with patching was qualitatively assessed and categorized as excellent (75-100\% compliance with prescribed patching regimen), good (50-74\% compliance), fair (25-49\% compliance) or poor (25\% compliance).

Demographic and clinical profile of each participant are shown in Table 1.

\section{Procedures}

\section{Sweep-VEP acuity and interocular grating acuity difference}

Monocular grating acuity testing was performed with the patient wearing his/her best optical correction and technical details were described elsewhere (Salomão et al, in press). Briefly the stimuli were phase-reversal sine-wave gratings presented on a 17.5 inches $(29 \times 38 \mathrm{~cm})$ high-resolution monochromatic video monitor (M20DCD4RE-Richardson Eletronics $\left.{ }^{\circledR}\right)$. Mean luminance $\left(140 \mathrm{~cd} / \mathrm{m}^{2}\right)$ was constant throughout the session. The EEG was recorded from two bipolar placements $\left(\mathrm{O}_{1}\right.$ and $\left.\mathrm{O}_{2}\right), 2-3 \mathrm{~cm}$ to the left and right of a ground electrode placed $1 \mathrm{~cm}$ above the inion on the midline. A reference electrode was placed in the vertex $\left(\mathrm{C}_{\mathrm{z}}\right)$. The potential differences were amplified (gain $=10,000 ;-3$ db cutoff at 1 and $100 \mathrm{~Hz}$ ). When the child was alert and fixating the monitor, an observer pressed the mouse button and the EEG was recorded and adaptively filtered (bandpass) in real time (sampling rate $=$ $397 \mathrm{~Hz}$ ) to isolate the VEP. Amplitude and phase of the first and second harmonics of the stimulus frequency were calculated.

Grating acuity was measured by sweeping spatial frequency at a fixed contrast $(80 \%)$. Spatial frequencies ranged from 0.1 to 28.0 cycles per degree (cpd) with testing distances from 30 to $150 \mathrm{~cm}$, according to age and fixation quality. Patterns were temporally alternated in counter-phase with a temporal modulation of $6.6 \mathrm{~Hz}$ for all tests. Grating acuity was estimated with an automated algorithm which performs a linear fit and extrapolation to zero amplitude for the final descending limb of the function relating VEP second harmonic amplitude to linear spatial frequency. A signal-to-noise ratio (SNR) at peak mean amplitude of 3:1 was required.

Grating acuity scores were transformed from cycles per degree to logarithm of the minimal angle of resolution (logMAR). Interocular grating acuity difference was calculated by subtracting the absolute scores from each eye and compared with normative values (Salomão et al, in press). Amblyopia was present when IAD was $\geq 0.10 \log$ MAR and its severity was considered as mild (0.11-0.30 $\log \mathrm{MAR})$, moderate (0.31$0.7 \log \mathrm{MAR})$ and severe $(\geq 0.71 \log \mathrm{MAR})$.

\section{RESULTS}

Interocular grating acuity differences were determined for all 27 patients with unilateral cataracts and ranged from 0.26 $\log$ MAR to $1.07 \log$ MAR. Mean IAD was $0.58 \pm 0.20 \log$ MAR 


\begin{tabular}{|c|c|c|c|c|c|c|c|c|}
\hline Id & Age & Gender & Aphakia & $\begin{array}{l}\text { Age of surgery } \\
\text { (months) }\end{array}$ & $\begin{array}{l}\text { Age of optical } \\
\text { correction (months) }\end{array}$ & $\begin{array}{c}\text { IAD } \\
\log M A R\end{array}$ & $\begin{array}{l}\text { Intensity } \\
\text { of opacity }\end{array}$ & $\begin{array}{l}\text { Another } \\
\text { findings }\end{array}$ \\
\hline 1 & 7.1 & $\mathrm{~m}$ & Aphakic & 4.0 & 4.5 & 0.53 & $\mathrm{M}$ & Strabismus \\
\hline 2 & 25.5 & $\mathrm{~m}$ & Pseudophakic & 17.6 & 18.0 & 0.82 & $\mathrm{~S}$ & Strabismus \\
\hline 3 & 18.6 & $\mathrm{~m}$ & Pseudophakic & 15.6 & 16.0 & 1.07 & $\mathrm{~S}$ & Strabismus \\
\hline 4 & 16.3 & $f$ & Aphakic & 12.3 & 13.0 & 0.36 & $\mathrm{~S}$ & Strabismus \\
\hline 5 & 17.4 & $f$ & Pseudophakic & 10.9 & 18.0 & 0.44 & $\mathrm{~S}$ & \\
\hline 6 & 25.0 & $f$ & Pseudophakic & 23.9 & 28.0 & 0.57 & M & \\
\hline 7 & 9.0 & $f$ & Aphakic & 8.2 & 10.0 & 0.48 & M & Strabismus \\
\hline 8 & 7.1 & $f$ & Aphakic & 5.0 & 6.0 & 0.58 & $\mathrm{~S}$ & Strabismus \\
\hline 9 & 18.3 & $f$ & Aphakic & 13.9 & 18.0 & 0.58 & $\mathrm{~S}$ & Strabismus \\
\hline 10 & 25.3 & $f$ & Aphakic & 8.3 & 9.0 & 0.51 & M & Strabismus \\
\hline 11 & 31.9 & $f$ & Aphakic & 9.5 & 10.0 & 0.72 & $\mathrm{~S}$ & Strabismus \\
\hline 12 & 29.5 & $f$ & Aphakic & 9.2 & 9.5 & 0.34 & $\mathrm{~S}$ & Strabismus \\
\hline 13 & 27.3 & $\mathrm{~m}$ & Aphakic & 10.1 & 11.0 & 0.54 & $\mathrm{~S}$ & Strabismus \\
\hline 14 & 11.3 & $f$ & Aphakic & 6.7 & 12.0 & 0.26 & $M$ & \\
\hline 15 & 8.0 & $f$ & Aphakic & 6.4 & 6.6 & 0.71 & $S$ & Strabismus \\
\hline 16 & 20.8 & $f$ & Aphakic & 10.9 & 15.0 & 0.79 & $\mathrm{~S}$ & Strabismus \\
\hline 17 & 10.6 & $f$ & Aphakic & 8.2 & 8.5 & 0.48 & $\mathrm{~S}$ & Strabismus \\
\hline 18 & 22.2 & $f$ & Aphakic & 17.5 & 18.0 & 0.49 & $\mathrm{~S}$ & Strabismus \\
\hline 19 & 27.5 & $f$ & Pseudophakic & 15.9 & 16.0 & 0.34 & $M$ & Strabismus \\
\hline 20 & 5.6 & $f$ & Aphakic & 2.3 & 4.0 & 0.54 & $S$ & Strabismus \\
\hline 21 & 22.3 & $\mathrm{~m}$ & Pseudophakic & 17.2 & 18.0 & 0.51 & $S$ & \\
\hline 22 & 16.2 & $f$ & Aphakic & 15.1 & 16.0 & 0.96 & $\mathrm{~S}$ & \\
\hline 23 & 12.4 & $f$ & Aphakic & 8.8 & 13.0 & 0.51 & M & Strabismus \\
\hline 24 & 14.0 & $\mathrm{~m}$ & Aphakic & 13.0 & 14.0 & 0.72 & S & Strabismus \\
\hline 25 & 30.3 & $f$ & Pseudophakic & 28.4 & 30.0 & 0.49 & $M$ & Strabismus \\
\hline 26 & 14.0 & $f$ & Aphakic & 12.2 & 13.0 & 0.77 & $\mathrm{~S}$ & Strabismus \\
\hline 27 & 4.13 & $\mathrm{~m}$ & Aphakic & 2.46 & 3.0 & 0.97 & $\mathrm{~S}$ & \\
\hline
\end{tabular}

$I d=$ identification; $A g e=A g e$ at the exam; $m=$ male; $f=$ female; $I A D=$ interocular acuity difference; $M=$ moderate; $S=$ severe

with a median of $0.54 \log$ MAR. Amblyopia was mild in 1 case, moderate in 17 cases and severe in 9 cases.

Mean interocular acuity difference in moderate opacity cases was significantly smaller $(0.46 \pm 0.10 \log$ MAR $)$ than those from dense opacities $(0.65 \pm 0.20 \log$ MAR $)$ by Student's $\mathrm{T}$ test $(\mathrm{t}=-2.4 ; \mathrm{p}=0.028)$.

Figure 1 shows the IADs values for cataract cases considering $0.10 \log$ MAR as maximum IAD limit for amblyopia diagnosis.

Patching compliance was excellent in 24 patients, good in 1 case and poor in 2 children. Since the majority has shown excellent compliance, no statistical analysis was necessary. Strabismus was present in 21 patients and their mean IAD $(0.60 \pm 0.19 \log \mathrm{MAR}$, with a median of $0.58 \log \mathrm{MAR})$ was comparable to that of 6 patients with aligned eyes $(0.62 \pm$ $0.28 \log$ MAR, with a median of $0.59 \log$ MAR) in 6 patients with aligned eyes $(\mathrm{T}=-0.307 ; \mathrm{p}=0.168)$.

Mean IAD in 20 aphakic children $(0.59 \pm 0.20 \log$ MAR, with a median of $0.58 \log$ MAR) was comparable to 7 pseudophakic patients $(0.62 \pm 0.25 \log$ MAR, with a median of 0.59 $\log$ MAR). However, surgery was performed earlier in the aphakic group (mean age $=9.2 \pm 4$ months) when compared with pseudophakic cases $(18.5 \pm 5.8$ months $)$.

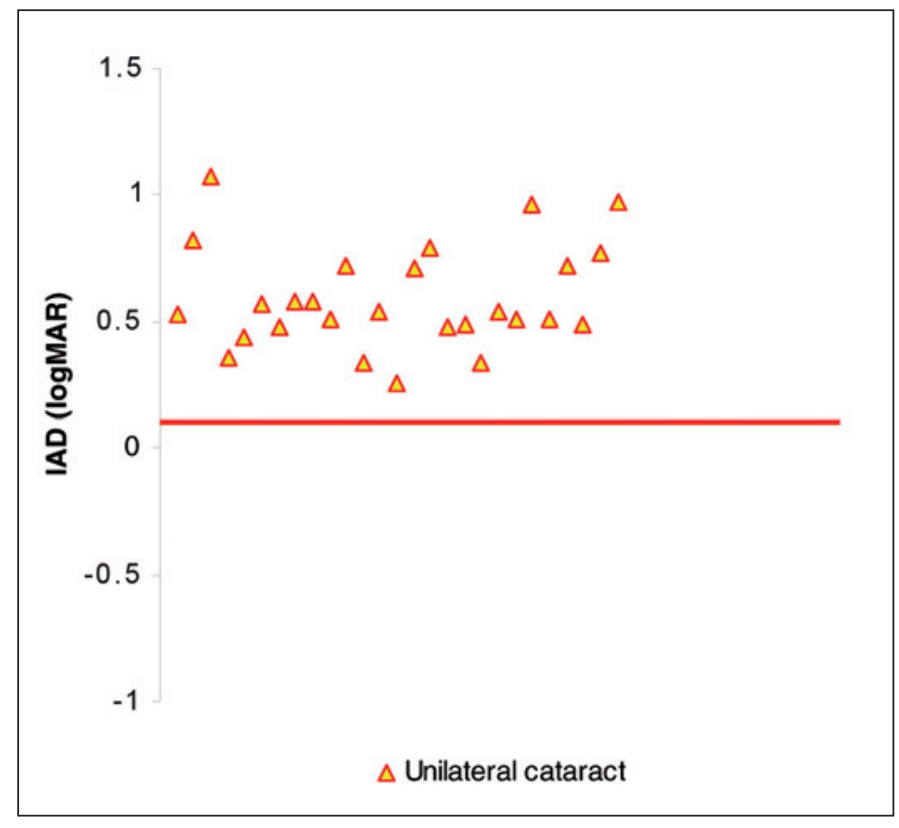

Figure 1 - IAD (logMAR) from unilateral cataract patients (triangles). The red line corresponds to the division value among the patients with (IAD>0.1 logMAR) that are shown in the upper part of the graph. 
No correlation was found between age of surgery and IAD (Pearson correlation coefficient $\mathrm{r}=0.10$ ).

\section{DISCUSSION}

Precise quantitative amblyopia diagnosis can be obtained by the determination of interocular grating acuity difference in infantile unilateral cataract. Amblyopia was very pronounced in this study (mean IAD was $0.58 \pm 0.20 \log$ MAR with a median of $0.54 \log$ MAR) in comparison with literature. Birch et al. ${ }^{(8)}$, studied 55 children with unilateral cataract operated untill the 6 weeks of age and observed mean IAD of $0.22 \log$ MAR. Drummond et al. ${ }^{(13)}$ evaluated 14 children with unilateral cataract who had surgery before the $17^{\text {th }}$ week of life, and had an IAD of $0.4 \log$ MAR. Wilson et al. ${ }^{(14)}$, reported mean $0.3 \log$ MAR IAD in 9 children operated before the $6^{\text {th }}$ week of life.

A major contributing factor for the discrepancy in the results is the delay in the surgical treatment in public Brazilian hospitals. Early cataract surgery, specifically during the first 6 weeks of life has been shown to be associated with better visual outcomes ${ }^{(15)}$. Lambert et al. ${ }^{(16)}$ studied VA outcomes from 25 infants who underwent unilateral cataract surgery. Mean age at surgery was 10 weeks, but those who had surgery after 4 months of life had an IAD worse than $0.8 \log$ MAR.

The harmful effects of unilateral visual deprivation to genicule-cortical architecture begins in the first week of life, with more severe cortical columns fragmentations in animal models the earlier the deprivation begins ${ }^{(17-19)}$.

In the current study no correlation was found between age of surgery and amblyopia. A possible explanation is that the vast majority of children had surgery after 6 months of life with only three cases operated before this age. Even with delayed surgery, moderate opacities showed better visual outcomes than those with severe cataract. Optical correction is also important to explain amblyopia severity in this studied group. Glasses can cause optical aberrations such as image magnification, induction of prismatic effect, restriction of visual field and mainly aniseikonia.

While patching compliance has been reported to be a critical variable in determining the visual outcome of children with unilateral congenital cataracts following cataract surgery ${ }^{(20-21)}$, there was not a clear correlation between patching compliance and the visual outcome in our study, because most of our patients had an excellent compliance.

\section{CONCLUSIONS}

Interocular grating acuity difference (IAD) in these case series of unilateral infantile cataract was pronounced. We believe that age at surgery as well as postoperative optical correction are critical factors which has contributed to the visual outcomes.

\section{RESUMO}

Objetivos: Determinar a diferença interocular da acuidade visual de resolução de grades em crianças operadas de catarata congênita unilateral. Métodos: Um grupo de 27 pacientes operados de catarata congênita unilateral tiveram mensurada sua acuidade visual monocular pelo potencial visual evocado de varredura. A diferença interocular foi calculada pela subtração absoluta das acuidades monoculares. A intensidade da opacificação, implante ou não de lente intraocular e presença de estrabismo foram consideradas para análise. Resultados: A média da diferença interocular foi de 0,58 $\pm 0,20 \log$ MAR. Esse resultado foi significantemente maior que $0,10 \log$ MAR, valor considerado como média normal nos estudos normativos. Crianças com opacidades intensas tiveram ambliopia mais pronunciada que os casos moderados. Não houve correlação significante entre a intensidade da ambliopia com estrabismo e afacia. Conclusões: A diferença interocular nesse grupo de crianças operadas de catarata congênita unilateral foi muito mais pronunciada que artigos prévios, provavelmente pelos atrasos no diagnóstico, intervenção cirúrgica e correção óptica.

Descritores: Ambliopia/etiologia; Catarata/congênito; Catarata/complicações; Complicações pós-operatórias

\section{REFERENCES}

1. Parks M. Lens. In: Paediatric ophthalmology. $2^{\text {nd }}$ ed. USA: Blackwell Science; 1997. p.445-76.

2. Lambert SR. Management of monocular congenital cataracts. Eye. 1999;13 (Pt 3b): 474-9. Review.

3. Bernardini MCP, Nassaralla Júnior JJ. Prevalência de ambliopia em um serviço oftalmológico de referência na cidade de Goiânia. Arq Bras Oftalmol. 1999; 62(2):169-76.

4. Albuquerque RC, Alves JGB. Afecções oculares prevalentes em crianças de baixa renda atendidas em um serviço oftalmológico na cidade do Recife - PE, Brasil. Arq Bras Oftalmol. 2003;66(6):831-4.

5. Ventura LMO, Travassos S, Ventura AG, Trigueiro L, Marques S. Um programa baseado na triagem visual de recém-nascidos em maternidades. Fundação Altino Ventura/2000. Arq Bras Oftalmol. 2002;65(6):629-35.

6. McCulloch DL, Skarf B. Pattern reversal visual evoked potentials following early treatment of unilateral, congenital cataract. Arch Ophthalmol. 1994;112(4):510-8

7. Buckley E, Lambert SR, Wilson ME. IOLs in the first year of life. J Pediatr Ophthalmol Strabismus. 1999;36(5):281-6.

8. Birch EE, Swanson WH, Stager DR, Woody M, Everett M. Outcome after very early treatment of dense congenital unilateral cataract. Invest Ophthalmol Vis Sci. 1993;34(13):3687-99.

9. Birch EE, Stager DR. The critical period for surgical treatment of dense congenital unilateral cataract. Invest Ophthalmol Vis Sci. 1996;37(8):1532-8.

10. Thompson DA, Moller H, Russell-Eggitt I, Kriss A. Visual acuity in unilateral cataract. Br J Ophthalmol. 1996;80(9):794-8.

11. Tyler CW, Apkarian P, Levi DM, Nakayama K. Rapid assessment of visual function: an electronic sweep technique for the pattern visual evoked potential Invest Ophthalmol Vis Sci. 1979;18(7):703-13.

12. Arai M, Katsumi O, Paranhos FR, Lopes De Faria JM, Hirose T. Comparison of Snellen acuity and objective assessment using the spatial frequency sweep PVER. Graefes Arch Clin Exp Ophthalmol. 1997;235(7):442-7.

13. Drummond GT, Sott WE, Keech RV. Management of monocular congenital cataracts. Arch Ophthalmol. 1989;107(1):45-51.

14. Wilson ME Jr, Trivedi RH, Hoxie JP, Bartholomew LR. Treatment outcomes of congenital monocular cataracts: the effects of surgical timing and patching compliance. J Pediatr Ophthalmol Strabismus. 2003;40(6):323-9; quiz 353-4. Comment in: J Pediatr Ophthalmol Strabismus. 2003;40(6):322. 
15. Birch EE, Cheng C, Stager DR Jr, Felius J. Visual acuity development after the implantation of unilateral intraocular lenses in infants and young children. $\mathrm{J}$ AAPOS. 2005;9(6):527-32.

16. Lambert SR, Lynn M, Drews-Botsch C, DuBois L, Plager DA, Medow NB, et al. Optotype acuity and re-operation rate after unilateral cataract surgery during the first 6 months of life with or without IOL implantation. Br J Ophthalmol. 2004;88(11):1387-90.

17. Horton JC, Hocking DR. Timing of the critical period for plasticity of ocular dominance columns in macaque striate cortex. J Neurosci. 1997;17(10):3684-709.
18. LeVay S, Wiesel TN, Hubel DH. The development of ocular dominance columns in normal and visually deprived monkeys. J Comp Neurol. 1980;191(1):1-51.

19. Gelbart SS, Hoyt CS, Jastrebski G, Marg E. Long-term visual results in bilateral congenital cataracts. Am J Ophthalmol. 1982;93(5):615-21.

20. Moore BD. Pediatric aphakic contact lens wear: rates of successful wear. J Pediatr Ophthalmol Strabismus. 1993;30(4):253-8.

21. Lloyd IC, Dowler JG, Kriss A, Speedwell L, Thompson DA, Russell-Eggitt I, Taylor D. Modulation of amblyopia therapy following early surgery for unilateral congenital cataracts. Br J Ophthalmol. 1995;79(9):802-6. 